\title{
CDX1 Gene
}

National Cancer Institute

\section{Source}

National Cancer Institute. CDX1 Gene. NCI Thesaurus. Code C107667.

This gene is involved in gene expression in the intestine. 